January, Capt. A. L. Kennedy gives an admirable survey of the services rendered by the League of Nations technical organizations in non-political fields. He stresses the value of the resettlement of populations in Greece under the League Commission as a contribution to European peace and indicates the need for dealing with questions of refugees and minorities which still persists. In regard to opium, the co-operation established at Geneva has resulted in a central office which maintains supervision over a complete branch of economic activity, from the import of the raw material to the consumption of the manufactured article and in checking its trans. port from one country to another. This achievement has, however, set the League the even harder task of suppressing the illegitimate traffic which still flourishes to a serious extent and also the task of controlling the raw material. Again, the League has provided a central body for collating and directing measures against the traffic in women and children, and it has every claim to be regarded as the world's ministry of health, not only co-ordinating health work in different countries, as well as research and standardization but also, as in the Singapore Epidemiological Intelligence Bureau, providing an intelligence service for the prevention of epidemics. Capt. Kennedy writes appreciatively of services rendered to China before the onslaught of Japan occurred as well as to the reconstruction work in Austria, the work of the Mandates Commission and of the International Labour Office and the Permanent Court of International Justice. This well-balanced assembly of facts leaves no room for doubt that if the failure to use the League in the political sphere led to its abandonment, we should require an exactly similar organization to carry on its present non-political activities if both nations and individuals are not to be deprived of services which have given and are giving them relief from want and suffering, higher moral and material standards and opportunities of a useful life.

\section{Scientific Research in New Zealand}

THE eleventh annual report of the Department of Scientific and Industrial Research, New Zealand, covers the year 1936-37, and, in addition to the secretary's report and the reports of the research committees of the Council, includes the reports of the Dominion Laboratory, the Geological Survey Branch, the Meteorological Branch and the Dominion, Apia and Magnetic Observatories. The Minister's covering statement refers to the establishment of a Bureau of Social Science Research, the work of which will include the co-ordination of the activities of research bodies or individuals in this field and the undertaking of investigations to assist the Govern. ment by providing the factual bases for social policy measures. Outstanding developments of the year were the reorganization of plant research under the Plant Research Bureau and the steps taken to establish an Animal Research Bureau. The Plant Diseases Division of the former Bureau has made good progress in the study of virus diseases of farm crops, par- ticularly tobacco, and has also completed comparative trials of new organic mercury dusts. Diseases of tomatoes and potatoes, etc., have also been investigated, and the Entomological Division of the Bureau has obtained satisfactory results in the biological control of the white butterfly, although new lines of attack for the control of the diamond black moth have been necessary. The Dairy Research Institute has made further progress in its study of the control of gas-producing organisms which cause openness in cheese, and has continued its studies of the elimination of the feed taint in butter and cream from certain districts.

THE Wheat Research Institute has continued to expand its long-range work on wheat breeding, while the Leather Research Laboratory has given special attention to methods of assessing the quality of leather as a guide to improvements. A particular group of chemical constituents has been studied in relation to the wearing-value of leather. An extensive programme of fruit research has included an attack on the problem of the mouldy core of apples and the control of internal cork of apples, while the soil and land utilization survey has been continued to give a fairly complete picture of the agricultural resources of the Hawke's Bay province. Other features of the year have been the establishment of the Standards Institute, which has already done much to promote the adoption of standards and establish committees and sub-committees covering a wide range of subjects. Evidence is already available of the benefits of this work to the Dominion. Research associations have been developed during the year in connexion with the tobacco, wool manufacturing and footwear manufacturing industries, and a feature of staff appointments during the year has been the recruitment of New Zealand science graduates who had migrated overseas. Of the total expenditure of $£ 131,957$ of the Department, $£ 71,233$ is on research investigations, $£ 13,268$ of which is derived from industries and £13,243 from sales and miscellaneous recoveries. Expenditure on the Dominion Laboratory was $£ 17,261$ and on the Meteorological Office $£ 12,069$.

\section{The Ontario Research Foundation}

THE report of the Ontario Research Foundation for 1936 refers to the increased work carried out for industry. Two new laboratories for research on paints and on air-conditioning are now running smoothly. In the former, investigations on weathering tests and chemical analysis of white house paints, weathering of structural metal paints, etc., are in progress, while the latter is investigating the 'summer' comfort requirements in regard to temperature and humidity of people in Toronto. The work of the Textiles Division has been concerned with the development of a textile oil for use in processing woollen materials as well as with the development of a process for highresistance tusser silk for electrical insulation purposes, and with processes for the reduction of shrinkage in textile materials. The Division of Engineering and Metallurgy has continued its studies 
on the effect of heat treatment on chilled cast-iron and on the forgeability of metals. The Division of Biochemistry has been concerned with the development of a new system of combination vegetable tannage for sale and transmission belting leather. A microscopic method for the early diagnosis of bovine mastitis has been worked out by the Division of Pathology and Bacteriology, while other work of the Foundation has been concerned with the deodorization and partial hydrogenation of cod liver oil without destroying the vitamin content, with the incidence of diseases of apples and related problems, and with a process for transferring pigments used in the paint industry from aqueous pastes to the oil phase.

\section{Desiccation in Africa}

A SUPPLEMENT to the Journal of the Royal African Society of January entitled "The Man-made Desert in Africa : Erosion and Drought" by Prof. E. P. Stebbing offers yet another warning that in many parts of the world drifting sand and eroding soil are beginning seriously to clog the wheels of administrative machinery. Erosion is a matter in which Africen Governments interfere unwillingly, for effective control often means uprooting social, agricultural and religious customs upon which tribal life, which British Governments strive to preserve, is based. In this paper, Stebbing regards erosion primarily from the point of view of its effect on water supplies, and believes that with increasing orosion, a falling water-table and decreasing water supplies, the character of the rainfall deteriorates, wet years becoming less, and droughts more frequent, and of longer duration. When deterioration has reached what Stebbing terms the "intermittent rainfall stage", where continuous agriculture is scarcely feasible, man has his last chance to change his methods and prevent the final encroachment of the desert. Much of Africa seems to have entered upon this critical stage of deterioration, and some parts have passed it irrevocably. Stebbing emphasizes that now "it is for the Administration to act". The immediate needs for Africa's conservation are more money and more officers trained to the work. Given. these, administrations might put into operation soil conservation programmes which, if carried out, would turn the scales, at or before the intermittent rainfall stage, against the desert's encroachment. The trouble is that we cannot tell, until we have tried them out, whether plans for soil conservation are compatible with plans for the harmonious social development of whites and blacks.

\section{Grass Seed Production}

THREE new bulletins have been issued in the Herbage Publication Series by the Imperial Bureau of Plant Genetics, Aberystwyth. Bulletin 19, "Production of Grass Seed" (price 5s.), is edited by R. O. Whyte and consists of an international exchange of opinions and experiences on the technique of producing seed of graminaceous herbage and forage plants. The countries represented are Scotland, Northern Ireland, New Zealand, the United States,
Germany and Sweden, the names and addresses of the contributors being supplied in each case. Bulletin 20, "Insect and other Pests injurious to the Pro. duction of Seed in Herbage and Forage Crops" (price 2s. 6d.), has been prepared by H. F. Barnes. This paper is essentially a summary of the available information concerning some of these pests, but although growers should find this most useful, they are nevertheless advised to consult the advisory entomologist in their particular area as to the best method for safeguarding their crops, as it is impossible to secure really satisfactory results without due attention to local conditions. Bulletin 21, "The Influence of Climatic Conditions on Type Composition", by Nils Sylvén (price 1s.), gives an account of experiments in Sweden on the changes induced in herbage plants grown for seed outside their proper growing districts. It is evident that there is consider. able danger of loss of valuable characters if this process is continued. For satisfactory results, seed must be obtained direct from the breeding station or its vicinity, and care taken to keep seed from the original source scrupulously apart from that grown in a different locality, or much of the value of the selection work will be lost.

\section{Education in the Indian Villages}

A Paper by Capt. J. W. Petavel before the Economics Society of Osmania University on September 24 last year emphasizes the value of educative employment in the economic system of the Indian village, and particularly that of the educational colony in Indian rural education. One of the greatest possibilities to be explored, however, is that of the use of educational colonies for town children and adolescents, and these should be for the benefit of poor middle-class people as well as for the working classes and should include secondary as well as primary education. Stress is laid in this system on productive work, and the scheme of factory colonies outlined is also advocated as a contribution to improved world relations. Both in the rural and in the factory colonies one of the primary needs is the co-operation of scientific men and other professional workers in leadership and on a part-time basis in teaching and other capacities. Moreover, the colony organization offers one of the best opportunities of dealing with India's root problem of increasing the productivity of the land to yield more food for her growing population. The establishment of a standing committee for unemployment and poverty problems, to plan and assist research in the directions indicated by the success of the Swiss labour colony of Witzwil, is also urged.

\section{Report of the University of Leeds}

THE University of Leeds report for 1936-37 records as the outstanding event of the year a gift of $£ 200,000$ by Mr. Frank Parkinson. It is significant that the report gives prominence to Mr. Parkinson's expressed belief "that the university can render the highest service to the community by keeping the realities of life and the need of breadth of vision in 